\title{
ANALYSIS OF REMEDIAL ACTIONS DESIGNED TO STABILIZE A HIGHWAY CUT IN A LANDSLIDE AREA
}

\author{
Peter TurČek, Monika Súlovská, Miloslav Kopecký, Jakub Panuška* \\ Slovak University of Technology, Faculty of Civil Engineering, Department of Geotechnics, Radlinského 11, \\ 81005 Bratislava, Slovak Republic \\ * corresponding author: jakub.panuska@stuba.sk
}

\begin{abstract}
The Carpathian flysch is widely recognized as a geological environment prone to slope movements. This fragility in such an environment is due to its complicated geological and hydrogeological conditions. Weakened slip surfaces (developed in clay like material), in combination with present or past tectonic activity and difficult hydrogeological conditions with aquifers under pressure, are the main causes of slope movements. The article proposes to analyze the design of remedial action in a landslide area near Žilina. Slip surfaces and water conditions are assumed regarding present geotechnical monitoring. Deep cut with two rows of pile walls is analyzed by the limit equilibrium method and finite element analysis. Interaction between two walls and the effect of an amount of volume of sliding mass on resultant earth pressures and anchor forces were studied. The results from finite element analysis are compared with analytical calculations and the differences are discussed.
\end{abstract}

KEYwORDS: Carpathian flysch, landslide stabilization, anchored pile wall.

\section{INTRODUCTION}

The environment of the Carpathian flysch creates complicated geological conditions. Often, layering of coarse permeable layers (sandstone, conglomerate which are also aquifers) with high strength, and in some places weathered soil like claystone in combination with tectonics, presents positive conditions for development of slope movements in the form of landslides and block deformations. Such movements often threaten manmade structures [1, 2]. Highway D1 near Žilina in part Lietavská Lúčka - Višňové passes through this landslide-prone area in the Carpathian flysch. Bridges, deep cuts and high embankments are constructed in this unstable relief. New slip surfaces and landslide areas were found in the locations of projected cuts during preparation phase. These instabilities were measured by recently installed inclinometers. Former designs, based on a paucity of information, had then to be revised.

Additional information about landslide activity, depth of slip surfaces and the geological environment were collected concurrently with the design of remedial actions. This information was systematically reviewed during the design of retaining structures. In most of the cases new findings resulted in significant modifications to the former design.

The finite element method (FEM) was used to study interaction effects between two walls and the effect of an amount of sliding soil mass on resultant earth pressures and anchor forces essential for the structural design of elements in the whole system.

\section{Geological Conditions on site}

The Highway in the presented section passes through an area which consists of partially masked older and also recent younger significant landslides. Some block type deformations were also found near an adjacent bridge. Formations of landslides were affected by tectonic activity in scarp parts and by erosion activity of a local stream in the toe. At the studied site the Paleogene saddle is covered by deluvial clays of low to intermediate plasticity. The clays are classified as firm to stiff. Paleogene formation made of claystone, sandstone and conglomerate is weathered to a depth of $15 \mathrm{~m}$. Tectonically fractured material contains the clay mineral - smectite. Several aquifers with pressurized water were found. These are usually connected to tectonics or layers of conglomerate or sandstone. Due to these complicated conditions the ground water level (GWL) was hit at different depths. The stable GWL was in 1999 found to be in depth $1.3 \mathrm{~m}$ below terrain with sometimes outflows from the borehole. These facts were confirmed during geotechnical monitoring (GTM). Outflow on terrain was observed in some open pipe piezometers. These findings confirmed also the pressurized character of GWL and indicate the necessity for installation of horizontal drainage boreholes (HOV). The effect of HOV on slopes stability was also evaluated by initial calculations which considered a lowering of GWL.

The scope of this article analyzes the design of cut support by a retaining wall $0.834-1.274 \mathrm{~km}$. The area was divided into two parts, one virgin not affected by landslides and the second one in a landslide prone area. Soil / rock parameters used in calculations (Table 1 and Table 2 were set according to broad geological studies which were done from 1999 [3-5] to 2016 and 
of comparable experience. The coordination of the site is in Figure 1 with the part marked for calculation. Figure 2 represents the geotechnical model put forward in this article. Deeper movements were found which were not in accordance with information from the geological survey. These movements were found at depths of $12 \mathrm{~m}$ and were observed during drilling of HOV. According to the geological survey the layer of conglomerates with pressurized water were probably hit. It is assumed that measured deformations of a magnitude of $10 \mathrm{~mm}$ in adjacent INK - 17 were caused by sudden decrease of water pressure in the aquifer. This resulted in immediate increase of effective pressure together with drag flow which activated movement. These movements were stabilized but activation of residual parameters of shear strength on the slip surface was assumed for the calculations. Deformations of max. $40 \mathrm{~mm}$ in depths from 2 to $9 \mathrm{~m}$ were measured by inclinometers installed in the studied area.

\section{DESIGNED REMEDIAL ACTIONS}

The maximum depth of cut is projected as $17 \mathrm{~m}$. Former designs were recalculated according to present measurements and findings. GEO5 software module "Sheeting check" was used to verify stability of the anchored pile wall. Overall slope stability was verified in module "Slope stability" with circular (Bishop) and polygonal (Sarma) slip surface. This paper analyses a cut of depth $15.35 \mathrm{~m}$ at $1.150-1.175 \mathrm{~km}$ (Figure 3) where the deepest movements were observed. The rest of the calculations follow similar assumptions and principles as those introduced at $\mathrm{km} \mathrm{1.150-1.175.} \mathrm{The}$ retaining wall was designed with increased pressure from creeping landslide [6]. The increased creeping pressure $E_{c r}$ is calculated as:

$$
E_{c r}=m(\varphi) \gamma \frac{h^{2}}{2} \cos ^{2} \varphi
$$

where $m(\varphi)$ is a multiplication factor for creeping pressure and depends on friction angle $\varphi$ and flexibility of structure (herein considered as 1.1), $\gamma$ is soil unit weight and $h$ is the height of sliding mass. Equation (1) is applicable if inclination of slip surfaces is more or less parallel to the surface of terrain, $\varphi=\beta$ (where $\beta$ is terrain inclination).

Peak shear strength parameters were used after stabilization of the sliding mass due to the idea that old slip surfaces were stabilized by a retaining structure which was designed to withstand these actions. Thus expected movements were considered in stable layers. One of the assumptions was that former slip surfaces with residual shear strength affect minimally newly developed ones under a retaining wall. Calculations considered also construction phases. The deepest excavation was considered $1 \mathrm{~m}$ below future road layers. Žilina is in a seismically active region and thus seismic actions were considered for design of retaining wall and slope stability analysis. These calculations were performed according to Mononobe-Okabe theory with horizontal $k_{h}$ and vertical $k_{v}$ (up and down) factors of acceleration. A surcharge of $20 \mathrm{kPa}$ was considered at the bottom of the excavation due to construction of road layers.

A complicated situation is also described by number of evaluated sections along a 440 length of cut. Nine characteristic sections were considered with different geotechnical models and depth of slip surfaces. The design of remedial actions reflects different boundary conditions.

The most critical section (Figure 3) will be shown as an example. Slip surface at depth of $12 \mathrm{~m}$ was identified according to measurements on INK -17 . The ground water level before constructions reached a maximum level $0.5 \mathrm{~m}$ below terrain. During optimization of solution a cut with a depth of $15.35 \mathrm{~m}$ stabilized by one row of pile wall seemed to be not a relevant and feasible solution.

The upper part of the pile wall will be constructed after an excavation of $0.5-1.0 \mathrm{~m}$. Piles will be constructed of concrete C30/37 with diameter of $900 \mathrm{~mm}$, length $16 \mathrm{~m}$ with spacing $1.3 \mathrm{~m}$. Anchors in position $0.5 \mathrm{~m}$ below the pile head will be installed after a subsequent excavation of $1.5 \mathrm{~m}$. Anchors were designed with total length $32 \mathrm{~m}$ ( $26 \mathrm{~m}$ free length, $6 \mathrm{~m}$ fixed length), inclined $30^{\circ}$ from the horizontal with a spacing $1.3 \mathrm{~m}$. Pre-stressing force was set to $400 \mathrm{kN}$. The fixed part has to be placed in position below the slip surface in an intact claystone environment and thus a steep inclination of $30^{\circ}$ with long free length $26 \mathrm{~m}$ was designed. Increased pressure from the creeping landslide was calculated according to 6]. Additional force $54.62 \mathrm{kN} / \mathrm{m}$ uniformly distributed up to a depth of $10 \mathrm{~m}$ was set as an additional load to earth pressures behind the wall. Earth pressures were solved by GEO5 software according to the method of dependent pressures. The bottom wall was modelled as a single wall with surcharge (the effect of the upper part). The cut at the upper wall has a depth of $4.5 \mathrm{~m}$.

A bench with width of $5 \mathrm{~m}$ was designed between the upper and bottom wall due to maintenance and decrease of earth pressures acting on the bottom wall. The bottom wall is designed as a pile wall constructed of concrete C30/37 with pile diameter $900 \mathrm{~mm}$, length $18 \mathrm{~m}$ and spacing $1.3 \mathrm{~m}$. Two rows of anchors were designed due to excavation to depth $9.1 \mathrm{~m}$. Positions of anchors are at depths 1.0 and $5.5 \mathrm{~m}$ below the pile head. Anchors were designed with total length $32 \mathrm{~m}$ ( $23 \mathrm{~m}$ free length, $8 \mathrm{~m}$ fixed length), inclined $30^{\circ}$ from horizontal with spacing $1.3 \mathrm{~m}$. Pre-stressing force was set to $450 \mathrm{kN}$.

The water level is assumed to decrease with excavation in combination with horizontal drainage boreholes. Permanent horizontal drains will be installed to achieve efficient draining of the environment behind the wall. This effect was observed on different constructions in similar geological conditions. Difference of water levels behind and in front of the wall was 


\begin{tabular}{llllllll}
\hline Soil / rock & $\begin{array}{l}\varphi_{\text {sat }}^{\prime} \\
{\left[\mathrm{kN} / \mathrm{m}^{3}\right]}\end{array}$ & $\begin{array}{l}\varphi^{\prime} \\
{\left[\mathrm{kN} / \mathrm{m}^{3}\right]}\end{array}$ & $\begin{array}{l}\delta \\
{[\mathrm{o}]}\end{array}$ & $\begin{array}{l}\nu \\
{[\mathrm{kPa}]}\end{array}$ & $\begin{array}{l}\mathrm{E}_{\text {def }} \\
{[\mathrm{o}]}\end{array}$ & $\begin{array}{l}\nu \\
{[\mathrm{MPa}]}\end{array}$ \\
\hline Deluvial clay / debris & 20.0 & 21.0 & 17.0 & 15.0 & 8.5 & 0.4 & 5 \\
\hline Weathered claystone & 20.5 & 21.5 & 22.0 & 16.0 & 11.0 & 0.35 & 20 \\
\hline Partially weathered claystone & 22.0 & 23.0 & 22.0 & 30.0 & 11.0 & 0.3 & 60 \\
\hline Tectonically disturbed claystone & 21.2 & 21.5 & 20.0 & 16.0 & 9.5 & 0.4 & 20 \\
\hline
\end{tabular}

TABLE 1. Soil/rock parameters used in calculations.

\begin{tabular}{llllll}
\hline Soil / rock & $\mathrm{E}_{50}$ & $\mathrm{E}_{\text {oed }}$ & $\mathrm{E}_{u r}$ & $\nu_{u r}$ & $\mathrm{~m}$ \\
{$[\mathrm{MPa}]$} & {$[\mathrm{MPa}]$} & {$[\mathrm{MPa}]$} & {$[\mathrm{MPa}]$} & {$[-]$} & {$[-]$} \\
\hline Deluvial clay / debris & 5.0 & 5.0 & 15.0 & 0.25 & 0.6 \\
\hline Weathered claystone & 20.0 & 20.0 & 60.0 & 0.2 & 0.6 \\
\hline Partially weathered claystone & 60.0 & 60.0 & 180.0 & 0.2 & 0.6 \\
\hline Tectonically disturbed claystone & 20.0 & 20.0 & 60.0 & 0.2 & 0.6 \\
\hline
\end{tabular}

TABLE 2. Soil/rock parameters used in FEM calculations.

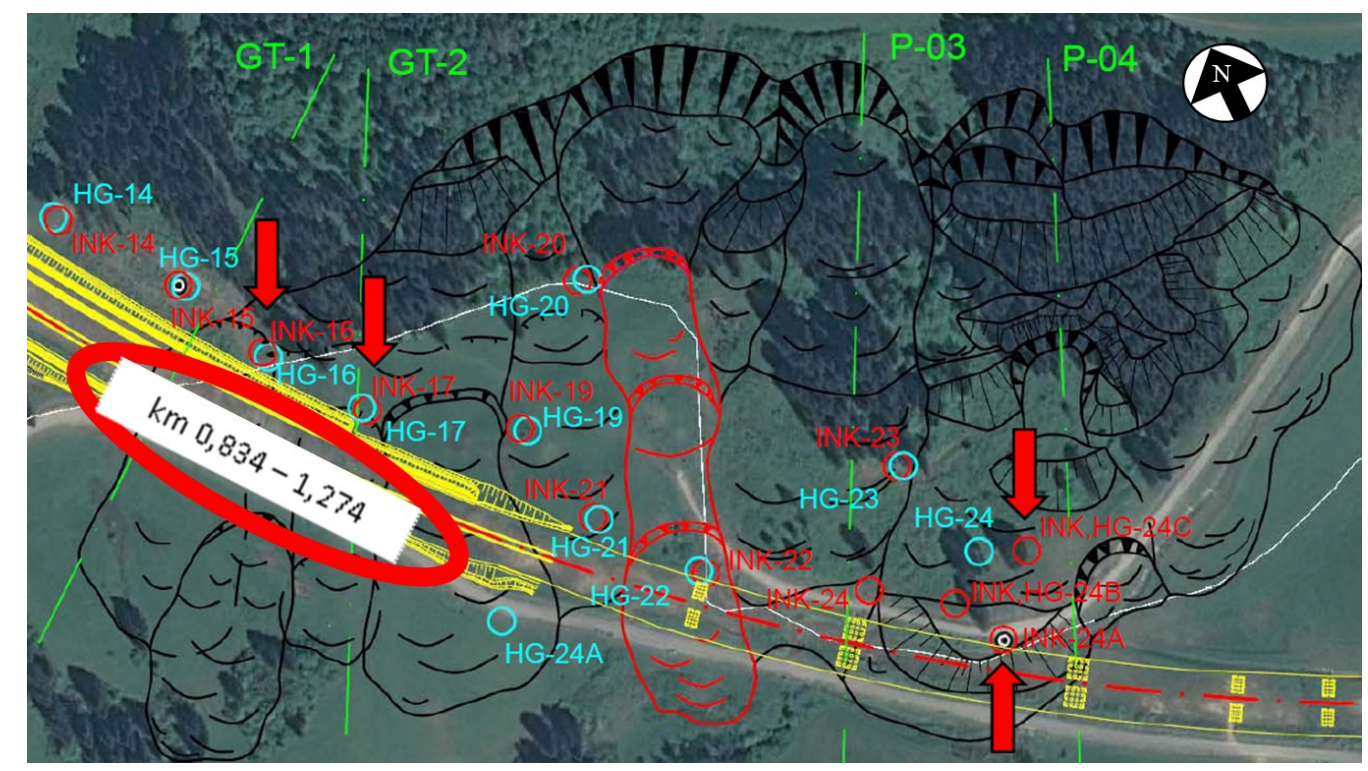

Figure 1. Landslides map with inclinometers (red circles) and open-pipe piezometers (blue circles).

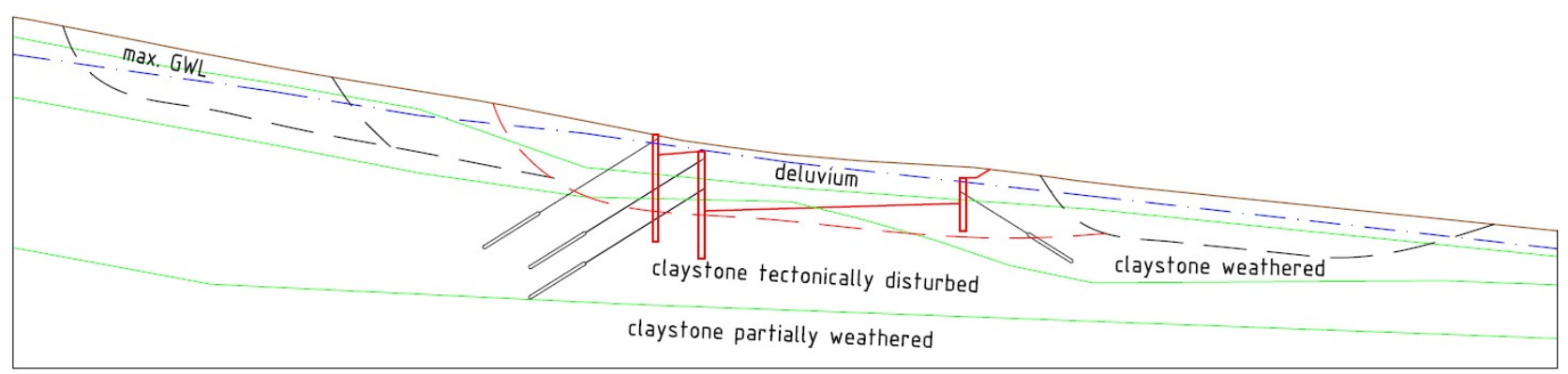

Figure 2. Geotechnical section 2 through INK-17. 


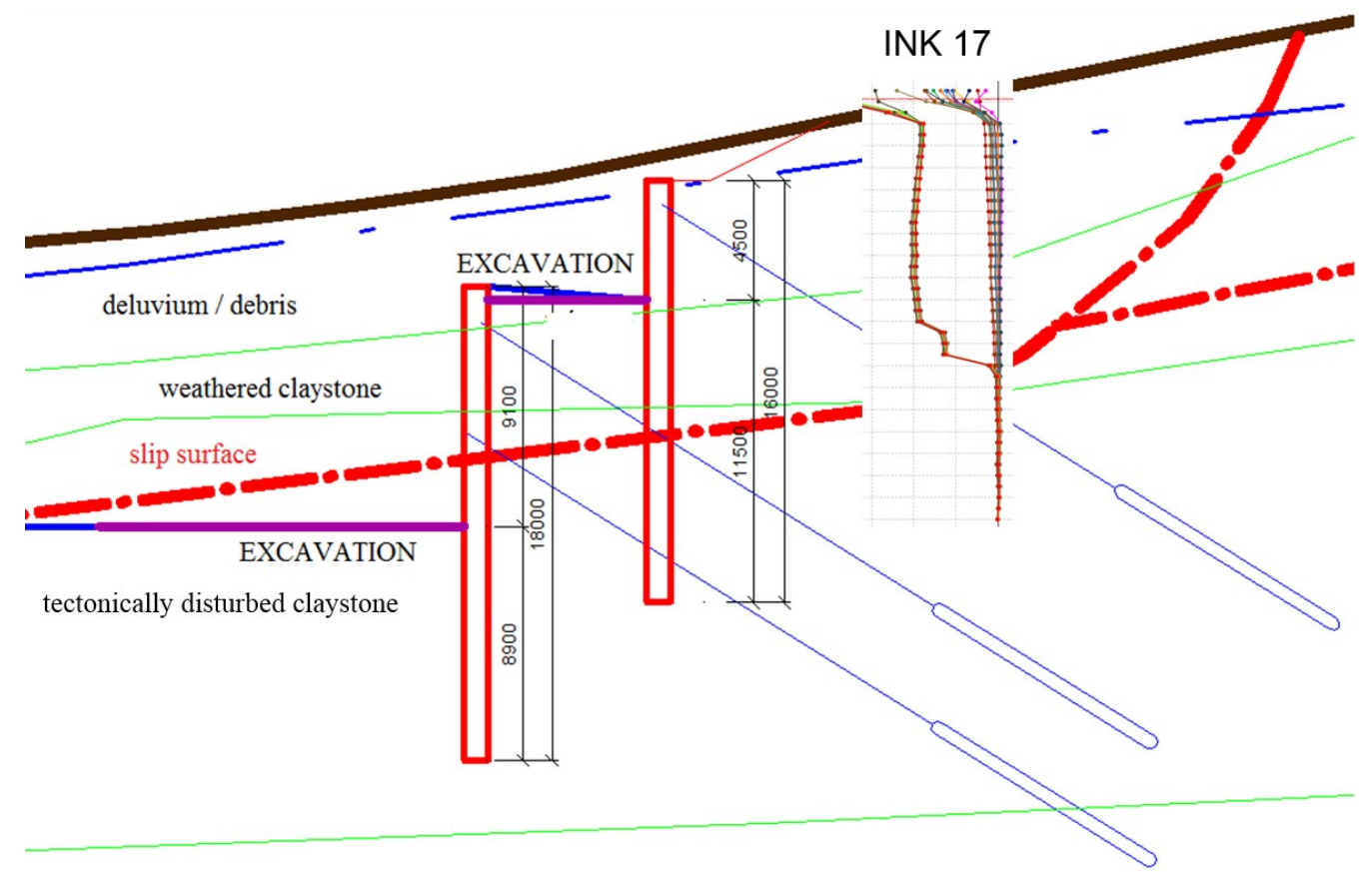

Figure 3. Geotechnical model at km 1.150-1.175.

assumed as $3 \mathrm{~m}$ during excavations. This assumption has to be verified during excavation through measurements in adjacent open pipe piezometers due to the presence of sandstone and conglomerate lenses with pressurized water. Characteristic pull out resistance was set to $150 \mathrm{kN} / \mathrm{m}$ of the fixed part. This value was measured during load tests of the anchors [7].

\section{Finite ELEMENT ANALYSIS}

Three sub-tasks were analyzed to verify assumptions made by the authors and to verify the safety of the design. The first task is interaction between the upper and bottom walls. The second task is verification of the assumption that old active slip surfaces will be successfully stabilized and thus peak shear strength parameters can be used because newly developed slips surfaces will develop in an undisturbed environment. Thus residual parameters on old slip surfaces and also old active slip surfaces affect minimally the resulting safety factor. The third task was to analyze the effect of activation of multiple sliding masses (SM). Activation of three possible SM was considered.

The geotechnical model used in the FEM calculation (and also for limit equilibrium slope stability) is in Figure 4

Finite element software PLAXIS was used for modelling of walls interaction. The hardening soil material model (HSM) was used because of its capability to model unloading/reloading stiffness and thus model deformations after excavation more realistically. This model also includes shear and volumetric hardening with increasing strains [8]. Choice of input stiffness parameters was based on statistical processing of in-situ pressure meter tests [5], laboratory tests (oedometer) [5] and comparable experience. Parameters for
FEM calculation are in Table 2. Parameter $m$ for modeling stress dependency of stiffness was chosen rather arbitrarily. Angle of dilation $\psi$ was assumed as $0^{\circ}$. Due to insufficient information on deformation parameters the FEM model was used just to verify the mechanism of walls interaction. Due to insufficient information on deformation parameters the FEM model was used just to verify the mechanism of walls interaction. Residual parameters at the given site were back calculated as $\varphi_{(r)}=12^{\circ}$ and $c_{r}=0 \mathrm{kPa}[9$. These parameters were applied to a discrete zone of slip surface $(1 \mathrm{~m})$ in the FEM calculation. Residual parameters at different slips surfaces were activated at different stages of calculation to consider the effect of an amount of sliding mass. Excavation stages were considered as they are expected to be performed during constructions works.

\section{Analysis of the Results}

Horizontal earth pressures $\sigma_{H}$ and effective geostatic/vertical stress $\sigma_{V}$ behind the wall and in front of the wall were extracted from the FEM calculation from elements adjacent to the structure. Total force $F_{i}$ from acting horizontal pressure $\sigma_{H i}$ was obtained by the integration of pressure over the length of the structure $L[10]$ :

$$
F_{i}=\int_{0}^{L} \sigma_{H i} d L
$$

Maximum/limiting lateral earth pressures were calculated from vertical effective stresses obtained by the FEM calculation. Limiting earth pressures $\left(\sigma_{a}-\right.$ active case and $\sigma_{p}$ passive case) for cohesive soil were 


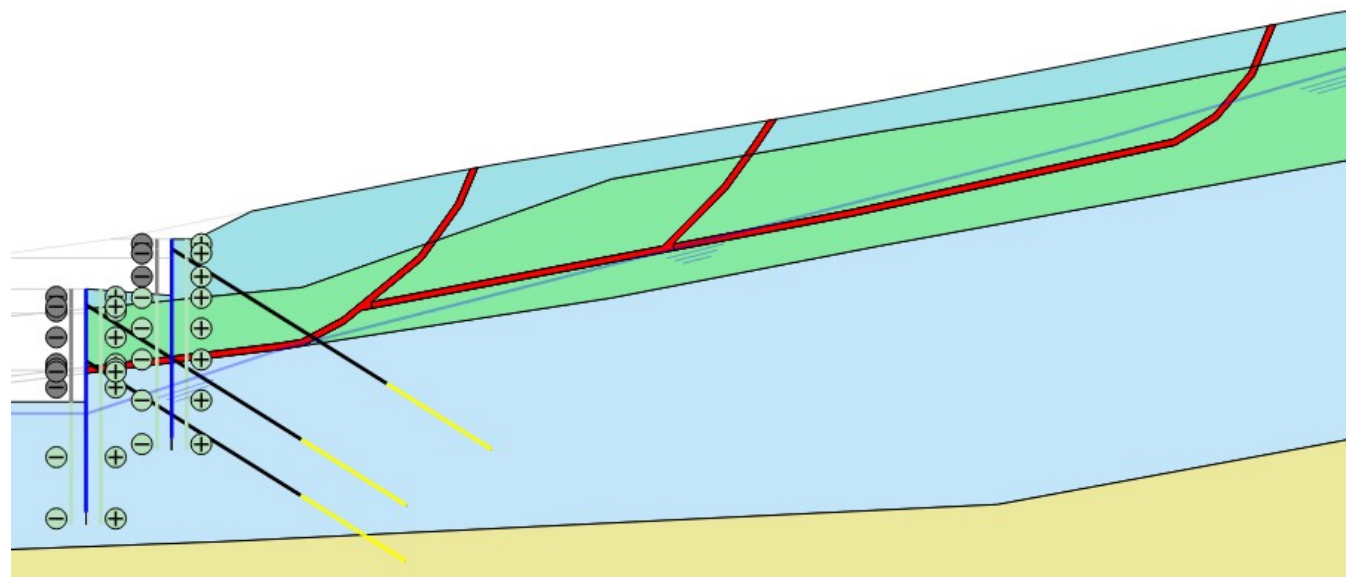

FiguRE 4. Geotechnical model at km 1.150-1.175 with three slip surfaces expected.

calculated as:

$$
\begin{gathered}
\sigma_{a}=\sigma_{v} K_{a}-2 c^{\prime} \sqrt{K_{a}} \\
\sigma_{p}=\sigma_{v} K_{p}+2 c^{\prime} \sqrt{K_{p}}
\end{gathered}
$$

where $K_{a}$ and $K p$ are coefficients of active and passive pressures respectively according to Coulomb with due consideration of terrain inclination and soil / wall friction.

Horizontal effective stresses for one activated sliding mass (1SM) are shown in Figure 5 a with additional load $\left(E_{c r}=546.2 \mathrm{kN}\right.$ - independent of sliding volume activated) in GEO5. It is shown that the magnitudes of the stresses from the FEM calculation in comparison with stresses from GEO5 $\left(E_{c r}+\right.$ earth pressures) are almost the same. The difference in resultant force after integration along the depth of the wall is approximately $50 \mathrm{kN} / \mathrm{m}$. Horizontal effective stresses acting on the bottom wall are shown in Figure $5 \mathrm{p}$. A small increase in stresses acting on the wall is shown by FEM calculation. Difference in pressures for the bottom wall is higher than in the case of the upper wall. The difference is $160 \mathrm{kN} / \mathrm{m}$ with the FEM model (higher stress for FEM) for the active case and $300 \mathrm{kN} / \mathrm{m}$ with the FEM model (higher stress for FEM) for the passive case. The retaining structure will be able to mobilize additional passive resistance and resist and withstand even the increased forces found in the FEM model. Additional mobilization of anchors is also possible. A difference in anchor forces is almost $150 \mathrm{kN}$ (max. force $633.63 \mathrm{kN}-\mathrm{FEM}$ in case of 3SM activated). This value is slightly above the resistance due to max. pull out resistance $605.32 \mathrm{kN}$ with partial safety factor $\gamma=2$. Passive and active limit states behind the structure showed that resultant pressure is in between the active and passive case. This seems to be obvious while pre-stressing forces are applied and act in opposite direction to the sliding mass. It is evident that in both cases, upper wall and bottom wall, the closest places to the passive case are those where the anchors are placed.
If additional force $E_{c r}$ was added in GEO5 enough deformation was achieved to mobilize active pressure. Creeping force $E_{c r}$ is about $250 \mathrm{kN} / \mathrm{m}$ higher than the difference between the phase with no SM activated and three SM activated which is $292.38 \mathrm{kN}$ (Table 3). Time effects and creep were not modeled in FEM calculations.

Results for the different SM (up to three sliding masses - 3SM) activated are in Figure 6 and in Table 3. As is shown forces in all anchors, and also earth pressures behind and in-front of the wall, are increasing with increasing activation of sliding masses. Increase in pressure is predominantly related to the zone near the slip surface. The increase in driving forces/pressures results in an increase in anchor forces and the mobilization of more passive resistance. These factors also influence internal forces and also deformations but these are yet to be analyzed. The change in the shape of pressure diagrams is not so dramatic. The upper wall is most affected by activation of multiple sliding masses. An increase of resultant forces in front of the structure is around $200 \mathrm{kN}$ for the upper wall. Forces behind the structure are increased above $300 \mathrm{kN}$ and forces in the anchors around $150 \mathrm{kN}$.

Resultant force in the front of the wall was almost unaffected by activation of multiple sliding masses. Forces behind the wall were increased as a result of additional mobilization of pressures in front of the upper wall. This also leads to an additional increase of forces in anchors. The sum of horizontal forces acting on the wall was calculated as:

$$
\begin{array}{r}
\sum F=\left(F_{\text {anchor }-1}+F_{\text {anchor }-2}\right) \cos \alpha+ \\
F_{\text {in }- \text { front }}-F_{\text {behind }}
\end{array}
$$

where $F_{\text {in-front }}$ is the resultant force in front of the structure obtained as integration of $\sigma_{\text {in-front }}$ over length of structure $L, F_{\text {behind }}$ is resultant force behind the structure, $F_{\text {anchor-1 }}$ and $F_{\text {anchor-2 }}$ are forces in the first or second row of anchors and $F S$ is the overall factor of safety after full excavation. As is shown Eq. (5) led to a positive result which means 


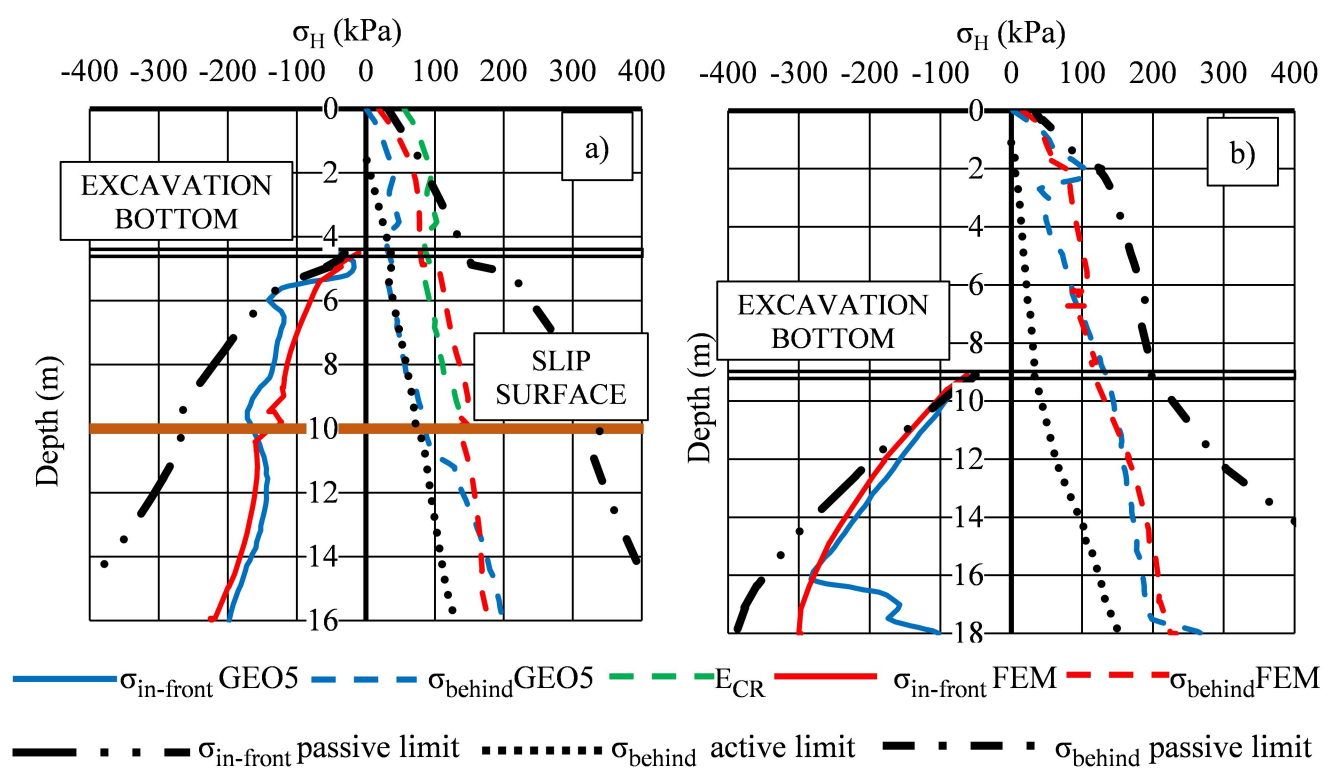

Figure 5. Horizontal effective stresses for one sliding mass activated a) upper wall; b) bottom wall.

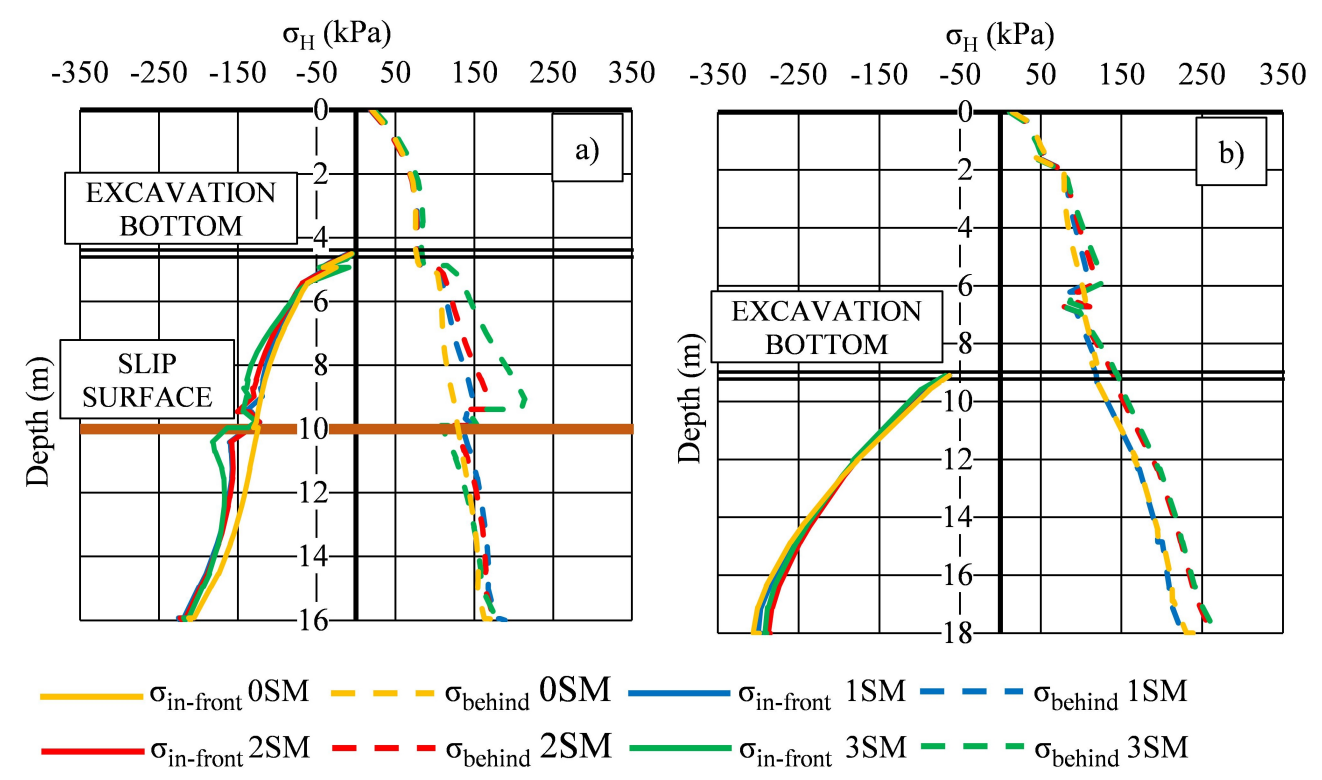

FigURE 6. Horizontal effective stresses for multiple sliding masses (SM) activated a) upper wall; b) bottom wall.

\begin{tabular}{lllllll}
\hline Case & $\begin{array}{l}F_{\text {in-front }} \\
{[\mathrm{kN}]}\end{array}$ & $\begin{array}{l}F_{\text {behind }} \\
{[\mathrm{kN}]}\end{array}$ & $\begin{array}{l}F_{\text {anchor }-1} \\
{[\mathrm{kN}]}\end{array}$ & $\begin{array}{l}F_{\text {anchor }-2} \\
{[\mathrm{kN}]}\end{array}$ & $\begin{array}{l}\sum_{\text {anchor }-1} \\
{[\mathrm{kN}]}\end{array}$ & $\begin{array}{l}F S \\
{[-]}\end{array}$ \\
\hline 0 SM upper wall & 1438.71 & 1784.57 & 480.92 & - & 70.63 & 1.35 \\
\hline 0 SM bottom wall & 1888.38 & 2386.94 & 553.57 & 599.48 & 500.01 & 1.35 \\
\hline 1 SM upper wall & 1576.61 & 1935.44 & 514.57 & - & 86.80 & 1.347 \\
\hline 1 SM bottom wall & 1876.11 & 2384.93 & 574.18 & 595.60 & 504.24 & 1.347 \\
\hline 2 SM upper wall & 1588.54 & 1955.27 & 518.02 & - & 81.89 & 1.355 \\
\hline 2 SM bottom wall & 1842.98 & 2651.77 & 574.58 & 558.31 & 172.32 & 1.355 \\
\hline 3 SM upper wall & 1642.00 & 2076.95 & 633.63 & - & 113.79 & 1.34 \\
\hline 3 SM bottom wall & 1871.58 & 2698.28 & 596.31 & 562.98 & 177.27 & 1.34 \\
\hline
\end{tabular}

TABLE 3. Results of FEM analysis. 
that passive forces are higher than triggering and thus stability can be achieved.

The difference between the safety factor for GEO5 and the FEM calculation is negligible $\triangle \mathrm{FS}=0.023$. Overall slope stability was verified in the first model with peak shear strength parameters because it is assumed that old slip planes are stabilized by pile walls which are designed to withstand these actions (an increase of load on the wall due to creeping landslide). Residual parameters in verification model 2 were set in the scarp area in case that newly developed movements will use present weak planes. The difference between these two models was $\Delta \mathrm{FS}=0.05$ (Bishop) and 0.07 (Sarma), which is a negligible difference. This tendency was also shown by the FEM calculations (Table 3) which in general lead to the same safety factor as in the case of limit equilibrium methods.

\section{Conclusions}

The article presents an analysis of the remedial actions designed to secure a future highway cut. The effect of multiple sliding masses activated and interaction of walls were considered. Analysis showed that an increasing volume of moving mass results in a slight increase of forces pressure acting on the upper wall. The bottom wall was in general affected almost in the same way due to a slight increase in anchor forces necessary to provide enough support for the toe of the upper wall.

The analytical solution provided a higher resultant force from creeping mass than modeled by FEM. Time effects and creeping behavior of sliding mass were not considered, which perhaps explains that observation. It is always beneficial to use analytical solutions and FEM calculation to observe possible mechanisms. A critical review with the pros and cons of both approaches has to be considered. Parametric study and possibly sensitivity analysis (which was done only partially in the presented article) should be carried out to observe different effects.

The possibility of progressive activation has to be verified through the conducted geotechnical monitoring. Forces in the anchors and slope movements have to be measured and the FEM model has to be calibrated. Assumptions about the stabilization of recent sliding mass and development of new slip surfaces in a virgin environment were confirmed and have to be proved during construction. Geotechnical monitoring is one of the essential steps as a part of the observational method in such a complicated environment as the Carpathian flysch. The obtained data will be used to carefully calibrate the model and to propose an optimized solution in future designs for the Carpathian Flysch.

\section{ACKNOWLEDGEMENTS}

The paper is a part of results from research project supported by Slovak agency VEGA No. 1/0882/16 "Influence of boundary conditions on limit states of geotechnical structures".

\section{REFERENCES}

[1] M. Kopecký, M. Ondrášik, J. Frankovská, D. Antolová. Landslides on the slopes of water reservoirs in the environment of carpathian flysch. In Proceedings of the 13th International Symposium Water Management and Hydraulic Engineering. Nakladatelstvo STU Bratislava, 2013.

[2] M. Kopecký, M. Ondrášik. Landslides on the route of the designed highway D1 in the area of inner carpathian flysch belt. In Proceedings of the 14th Danube-European Conference on Geotechnical Engineering. Slovak University of Technology, 2010.

[3] A. Matejček, E. Fussgänger. Geological documentation of survey boreholes; GEOFOS s. r. o., Žilina; D1 Lietavská Lúčka - Višňové, 06/1999.

[4] A. Matejček, E. Fussgänger. Geological documentation of archived survey boreholes; GEOFOS s. r. o., Žilina; D1 Lietavská Lúčka - Višňové, 06/1999.

[5] A. Matejček, E. Fussgänger, M. Panek, et al. Final report of a detailed engineering geological and hydrogeological survey; GEOFOS s. r. o., žilina; D1 Lietavská Lúčka - Višňové, 06/1999.

[6] H. Brandl. Retaining structures for rock masses. Butterworth-Heinemann, Oxford, 1994. DOI:https://doi.org/10.1016/C2013-0-01244-3

[7] P. Turček, J. Panuška. Design and confirmation of anchors at highway D1 on the section Lietavská Lúčka Višňové, 06/2017.

[8] T. Schanz, P. Vermeer, P. Bonnier. The hardening soil model: Formulation and verification. In Proceedings of the international symposium beyond 2000 in computational geotechnics. A.A. Bakema Publishers, USA, 1999.

[9] M. Súlovská, M. Kopecký, J. Panuška. Stabilization of landslide area for foundations of a highway bridge. In Proceedings of the 16th International Multidisciplinary Scientific GeoConference. SGEM, Sofia, 2016.

[10] Z. Chunmei, S. Wei, C. J.van.W. Comparing two methods to estimate lateral force acting on stabilizing piles for a landslide in the three gorges reservoir, china. Engineering Geology 173:41-53, 2014. DOI:https://doi.org/10.1016/j.enggeo.2014.02.004 